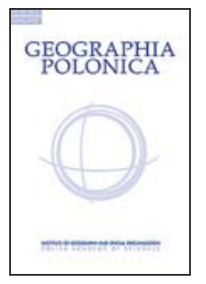

\title{
WHAT STRATEGIES MAKE COMPATIBLE THE STAKES OF NATURE CONSERVATION AND THE STAKES OF ECONOMIC GROWTH IN PROTECTED AREA? EXAMPLE OF EL KALA NATIONAL PARK, ALGERIA
} \author{
Université Frères Mentouri \\ BP 325, Route Ain EL Bey, 27017 Constantine: Algeria \\ e-mail: diaf_imene@umc.edu.dz \\ ${ }^{2}$ Département de Géographie (UFR08) \\ Université de Paris 1 Panthéon-Sorbonne \\ 191 rue Saint Jacques 75005 Paris: France \\ e-mail: Pierre.Pech@univ-paris1.fr
}

Diaf Imene ${ }^{1}$ • Touati Bouzid ${ }^{1}$ - Pierre Pech ${ }^{2}$

${ }^{1}$ Faculté des Sciences de la Terre, de la Géographie et de l'Aménagement du Territoire

\begin{abstract}
Public policies to protect natural environments are becoming increasingly integrated in many countries. However, in some countries, nature management policies do not pay much attention to issues raised by local populations, especially development issues. These seem often incompatible with the logic of protection of nature defended by the national administrations. Recent studies show that there are ways to make these issues compatible. The knowledge on this subject is still weak for the southern shore of the Mediterranean region. Our study focuses on the case of a natural park located in the northeast of Algeria: the sector of the El Kala National Park (EKNP). This territory faces a double strategic ambition: to strengthen the protection of nature but also to develop the agricultural economy and tourism. Our method relies on the analysis of 3 types of data: national statistics of Algeria, conservation and development strategy documents and satellite data. Our study shows an increase in the area of EKNP vegetation between 1995 and 2005.
\end{abstract}

\section{Key words}

conservation • tourism $\bullet$ protected areas $・$ local development $•$ El Kala National Park - Algeria

\section{Introduction}

The Mediterranean region is facing a grow-

ing population with an increasing demand for food and space (Malek et al. 2018).
This evolution has an impact on one of the world's biodiversity hotspots. As indicated in Table 1, a large number of authors report the vulnerability of the natural environments of the Mediterranean region. This exceptional 
Table 1. Table on taking into account threats to the biodiversity of the Mediterranean regions

\begin{tabular}{|c|c|c|}
\hline \multicolumn{2}{|c|}{$\begin{array}{l}\text { The Mediterranean region is, nowadays, one of the most significantly } \\
\text { altered hotspots in the world }\end{array}$} & $\begin{array}{l}\text { Medail \& Quezel 1997; Facucci et al. } \\
\text { 2007; Kefi et al. 2007; Lefevre et al. }\end{array}$ \\
\hline \multirow{3}{*}{$\begin{array}{l}\text { In the Mediterranean regions climate } \\
\text { change causes significant impacts } \\
\text { on biodiversity }\end{array}$} & Biodiversity loss & $\begin{array}{l}\text { Klausmeyer \& Shaw 2009; Lefevre } \\
\text { et al. } 2013\end{array}$ \\
\hline & $\begin{array}{l}\text { Climatic changes have caused } \\
\text { or contributed to tree mortality }\end{array}$ & Lefevre et al., 2013 \\
\hline & $\begin{array}{l}\text { Climatic changes increase the } \\
\text { frequency and intensity of extreme } \\
\text { events }\end{array}$ & $\begin{array}{l}\text { Quezel \& Medail 2003; } \\
\text { Lefevre et al. } 2013\end{array}$ \\
\hline \multicolumn{2}{|c|}{$\begin{array}{l}\text { The Mediterranean region has been affected by anthropic disturbance } \\
\text { for thousands of years and the pressure of human societies is, nowadays, } \\
\text { responsible for the erosion of biodiversity, and natural resources }\end{array}$} & $\begin{array}{l}\text { Brandt \& Thornes 1996; Ribeiro et al. } \\
\text { 2004; Facucci et al. 2007; Rudel } \\
\text { 2011; Lefevre et al. 2013; Malek } \\
\text { et al. } 2018\end{array}$ \\
\hline
\end{tabular}

biodiversity is highly threatened and is subject to the impacts of climate change (Malek et al. 2018), forest fires (Held and Montero Küpper 2001) and land clearance (Lefevre et al. 2013). Kefi et al. (2007) claim an imminent desertification.

Public policies to protect natural environments are initiated by international organizations and are increasingly integrated in many countries. At the country level and at local government level, there is a regulation for the protection of species (Abman 2018). As demonstrated by Joppa and Pfaff (2010) and Abman (2018), these nature protection policies are rooted in protected areas. IUCN defines categories of protected areas (Abman 2018) according to the intensity of protection. In parallel, some of the protected areas receive labels such as the MAB-UNESCO label. Then nationally, each country constitutes its methods of labeling, national and regional parks, reserves, etc. (Joppa \& Pfaff 2010). However, as said by Joppa and Pfaff (2010) and Lefevre and al. (2013), they often focus on limited areas. However, as said by Venter et al. (2008), in some countries, nature management policies do not pay much attention to issues raised by local populations, especially development issues. These seem often incompatible with the logic of protection of nature defended by the national administrations. As presented by Pyke (2007), there is a frequent contradiction between development issues based on the growth of usual economic activities and nature conservation issues. Recent studies show that there are ways to make these issues compatible. It is not a question of giving priority to one or the other but of bringing the two together while moving towards an integrated management of the protected territories. This requires a shift in the economic approach and the nature conservation approach. Significant changes have been initiated since the early 2000 s with the integration of sustainability strategies into protected areas, as shown for example by Venter et al. (2008). If the knowledge on this subject progresses for the countries of northern Europe and also for example in southern Africa where exemplary cases are described (Venter et al. 2008), the knowledge is weaker for the southern shore of the Mediterranean region (Held \& Montero Küpper 2001; Malek et al. 2018). The question of erosion of biodiversity is well understood by most countries bordering the Mediterranean. But it faces other priorities.

Our study focuses on the case of a natural park located in the northeast of Algeria: the sector of the El Kala National Park, also known as EKNP (Fig. 1). This territory faces a double strategic ambition: to strengthen the protection of nature but also to develop the agricultural economy and tourism. The question at stake is that of compatibility: how are the two issues compatible? What 


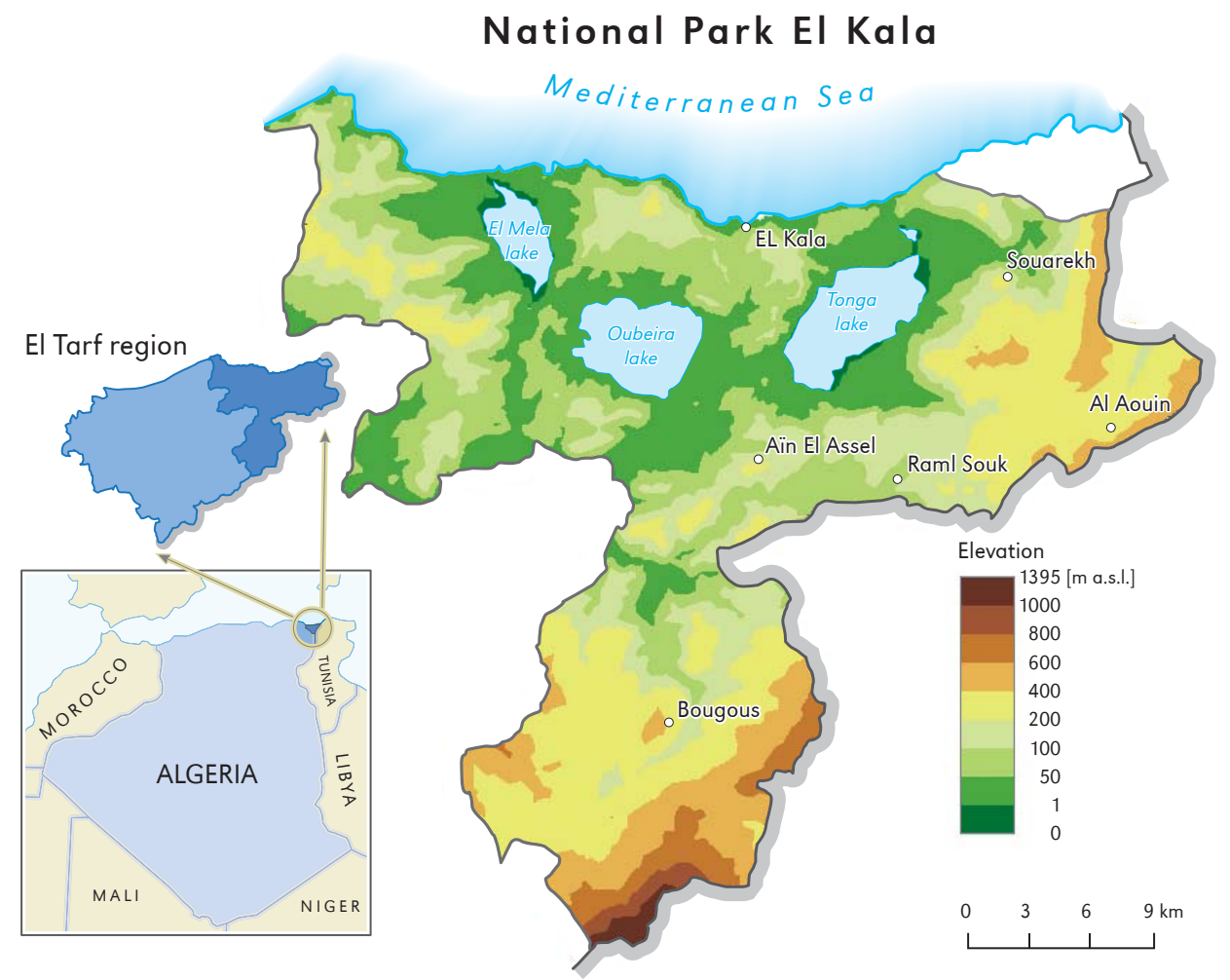

Figure 1. Location map: El Kala National Park, second largest park on the borders of eastern Algeria

elements make it possible to measure the efforts undertaken? What innovative solutions can be suggested based on experiences from other nearby or similar territories?

This paper proceeds as follows. Section 2 presents the area studied, the EKNP. Section 3 describes the method and the data used for estimation of the changes in the parameters studied for a little over a decade. Section 4 presents the results of these changes. Section 5 discuss them. The paper then concludes with final remarks and suggestions from the scientific literature and presenting integrated management practices in protected areas.

\section{Study area}

Created in July 1983, the El Kala National Park, located in the extreme northeast of Algeria, covers an area of about $800 \mathrm{~km}^{2}$ spanning both the coastal plain and mountainous hinterland. The coastal plain corresponds to a low, sandy coast with dune cords insulating lagoons. The coastal plain is made up of alluvial deposits. It is occupied by 3 lakes (Lake Mellah, Lake Oubeira and Lake Tonga). The southern half consists of a mountain rising to $1395 \mathrm{~m}$ above sea level. It is a mountain consisting of sandstone/gray flysch generating leached brown soils. Some areas are covered with forests that protect the mountain against erosion. These are forests of Aleppo pines and Mediterranean oak. The rainfall varies from 900 to $1200 \mathrm{~mm} /$ year (Bouazouni, 2004). All contains a mosaic of ecosystems made up of forests and wetlands, and all of them constitute a complex that is considered unique in the Mediterranean basin. The flora is characterized by a particularly high rate of endemic, rare and very rare 
species (De Belair 1990). Its faunal wealth is no less spectacular (Ouelmouhoub 2005): 189 species of birds, of which 21 are raptors have been documented there (Benyacoub \& Chabi 2000). Most notable are the wetlands, which are internationally renown, with 5 featuring on the RAMSAR wetland convention list. These include Tonga Lake, Lake Oubeira and Lake El Mellah (Fig. 1). The EKNP represents the largest protected area in northern Algeria and also the richest in biodiversity. These features have earned it the international status of Biosphere Reserve by UNESCO in 1993.

\section{Materials and methods}

As illustrated in Figure 2, our method relies on the analysis of 3 types of data: national statistics of Algeria according to its National Office of Statistics (NOS), conservation and development strategy documents and satellite data. Satellite data is used to measure the evolution of natural environments to measure the effectiveness of management measures. Then the results are confronted with the international scientific literature.

\section{Analysis of socio-economic statistics}

The Algerian National Office of Statistics make it possible to evoke the socioeconomic realities of the EKNP. We studied national statistics. These give little information on the territory of EKNP. In particular, tourism data are very poorly developed. We have therefore examined the data at our disposal, those relating to the modes of occupation of space, natural areas of forests and agriculture.

\section{Analysis of conservation and local development strategy documents}

Public documents concerning nature conservation and development strategies are studied using the TROPES software. We identify the words used to classify the documents by a notation system. Strategies for EKNP are compared to three other parks in three other countries. We studied strategies for tourism and agricultural development and nature protection strategies. The study of planning documents of the Algerian State (Tab. 2) allowed to take note of these strategies concerning the EKNP.

Then we wanted to compare them to documents that specify these strategies of other parks, taking two examples of natural parks in the Mediterranean region, the PNR Camargue, the Montsant Nature Park in Spain and the Kruger Park in South Africa. For these documents we have selected elements in the texts that allow to define notes for elements of strategies. These data are rated on a scale from -1 to +1 , with negative ratings indicating a lack of a strategy for protecting nature and biodiversity. The two notes on development contrast strategies rated +1 when strategies are oriented towards the sustainable development of tourism and agricultural development and -1 when it is a question of productivist and intensive strategies giving little priority to sustainability. We add a note on the use of consultation process, +1 when the

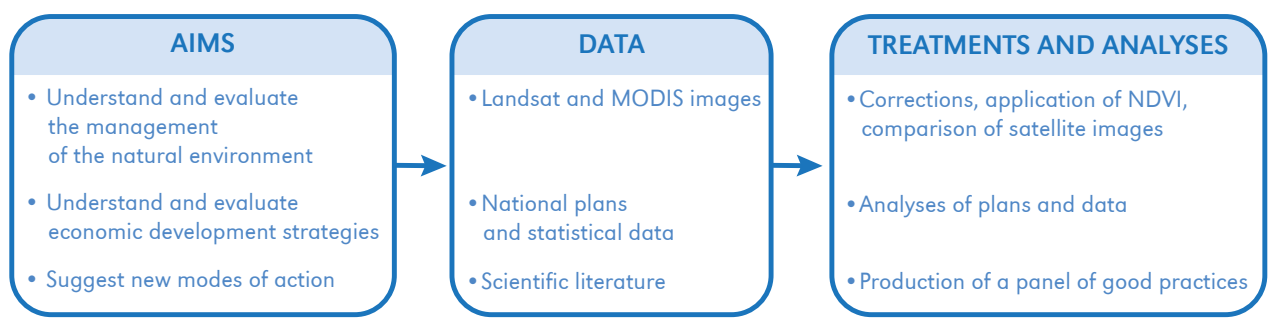

Figure 2. Working method 
Table 2. List of documents related to nature conservation and economic development strategies

\begin{tabular}{|c|c|c|}
\hline Number & Name in the text & Reference \\
\hline 1 & $\begin{array}{l}\text { CDP - Coastal Develop- } \\
\text { ment Plan }\end{array}$ & $\begin{array}{l}\text { Geosystem consulting, 2013. Etude pour l'élaboration du plan } \\
\text { d'aménagement cotier (Wilaya d'El Tark). Ministère de l'Aménagement } \\
\text { du Territoire et de l'Environnement, Alger. }\end{array}$ \\
\hline 2 & Bouazouni & $\begin{array}{l}\text { Bouazouni O., 2004. Projet régional pour le développement d'aires } \\
\text { marines et côtières protégées dans la région de la Méditerranée, Parc } \\
\text { National d'El Kala, étude socio-économique du PNEK. United Nations } \\
\text { Environment Programme, Mediterranean Action Plan, Regional Activity } \\
\text { Centre for Specially Protected Areas. }\end{array}$ \\
\hline 3 & EKNP Zoning & $\begin{array}{l}\text { Ministère de l'Aménagement et du Territoire et de l'Environnement, } 2008 . \\
\text { Zonage du parc national El Kala, Alger. }\end{array}$ \\
\hline 4 & SDAT & $\begin{array}{l}\text { Ministère de l'Aménagement du Territoire, de l'Environnement et du } \\
\text { Tourisme, 2008. Schéma Directeur de l'Aménagement Touristique, "SDAT } \\
\text { 2025", Alger, } 5 \text { volumes. }\end{array}$ \\
\hline 5 & Kruger Park & $\begin{array}{l}\text { Venter F.J., Naiman R.J., Biggs H.C., Et Al Pienaar D.J, 2008. The evolution } \\
\text { of conservation management philosophy: Science, environnemental change } \\
\text { and social adjustements in Kruger National Park. Ecosystems, vol. 11, no. 2, } \\
\text { pp. 173-192. }\end{array}$ \\
\hline 6 & Camargue PNR & $\begin{array}{l}\text { Parc Naturel Régional de Camargue, 2010. Charte. Objectif 2022. Rapport } \\
\text { Vol. 1. http://www.provence-plaisirs.com/pdf/charte_parc_naturel_camar- } \\
\text { gue.pdf [28 Feb. 2019]. }\end{array}$ \\
\hline 7 & Montsant Agenda 21 & $\begin{array}{l}\text { Generalitat de Catalunya, 2009. Agenda 21, Parc Natural de la Serra } \\
\text { de Montsant. }\end{array}$ \\
\hline
\end{tabular}

procedures are developed, -1 when they are absent. Intermediate scores are awarded: 0.75 when the trend is very good, 0.5 when it is acceptable, 0.25 when it is ok, 0 when it is average, -0.25 when the strategies are not very sustainable, -0.5 when they are insufficient, -0.75 when they are almost nonexistent. These data are gathered in two columns which make it possible to constitute two axes in the figure representing each strategic document by a point: an axis of the intensity of the note with respect to the strategies of protection of the nature and an axis concerning the strategies of development more or less durable to which is added the note concerning the consultation. We have collected all the metadata in Table 3.

\section{Satellite data analysis}

The issue here is to understand how vegetation cover evolved over the 20-year period 1995-2015 using data from satellite imagery.
The evolution of vegetation cover is analyzed by processing LANDSAT images from 1995, 2000, 2005, 2010, 2015 and MODIS images for the years 2000, 2005, 2010, 2015. The objective is to evaluate successive states of vegetation cover from cartographic data (Pech et al. 2007; Matuszkiewicz et al. 2013) and to question the impacts of management methods.

The metadata displayed in Table 4 is complementary and indispensable digital information for the interpretation, comparison and processing of satellite images. Other information, such as the elevation and the azimuth of the sun, makes it possible to provide radiometric corrections and thus to improve the reflectance of certain themes of the surface of the earth. Indeed, the images here selected have a very good quality with a minimum of estimated cloud cover close to $0 \%$.

The choice of LANDSAT images was based primarily on their availability on NASA websites. Satellite sensors are usually exposed 
Table 3. Metadata and interpretive data from strategic documents

\begin{tabular}{|c|c|c|c|c|c|c|c|}
\hline \multirow[t]{2}{*}{ Metadata } & $\begin{array}{l}\text { Nature protection } \\
\text { strategy, nature } \\
\text { management } \\
\text { methods in general } \\
\text { and integration } \\
\text { of environmental } \\
\text { concerns }\end{array}$ & $\begin{array}{c}\text { Strategy for } \\
\text { protecting } \\
\text { biodiversity, ways } \\
\text { of managing } \\
\text { biodiversity }\end{array}$ & $\begin{array}{l}\text { There are two } \\
\text { types of tourism } \\
\text { approaches and } \\
\text { management. } \\
\text { To +1, the } \\
\text { recommended } \\
\text { and regulated } \\
\text { practices in the } \\
\text { protected area } \\
\text { are sustainable, } \\
\text { respectful of the } \\
\text { environment, using } \\
\text { environmentally } \\
\text { friendly } \\
\text { accommodation } \\
\text { and conversely } \\
\text { intensive tourism } \\
\text { development } \\
\text { strategies are } \\
\text { noted -1 }\end{array}$ & $\begin{array}{l}\text { There are two types } \\
\text { of agricultural } \\
\text { development. } \\
\text { If the practices } \\
\text { recommended and } \\
\text { regulated in the } \\
\text { protected area } \\
\text { are sustainable, } \\
\text { using few fertilizers } \\
\text { and chemical } \\
\text { weed killers, with } \\
\text { organic farming and } \\
\text { valorization of the } \\
\text { local productions, } \\
\text { we note }+1 \text {, and } \\
\text { opposite - the } \\
\text { intensive agricultural } \\
\text { practices and } \\
\text { productivism are } \\
\text { rated }-1\end{array}$ & $\begin{array}{l}\text { The practices } \\
\text { of citizen } \\
\text { participation in the } \\
\text { development } \\
\text { of management } \\
\text { plans are noted } \\
+1 \text { and their } \\
\text { complete absence } \\
\text { is noted -1 }\end{array}$ & $\begin{array}{c}\text { The average score } \\
\text { is calculated for } \\
\text { nature } \\
\text { and biodiversity } \\
\text { protection strategies }\end{array}$ & $\begin{array}{c}\text { The average } \\
\text { of agricultural } \\
\text { and tourist } \\
\text { development } \\
\text { modes and } \\
\text { concertation } \\
\text { practices are } \\
\text { calculated }\end{array}$ \\
\hline & $\begin{array}{l}\text { nature } \\
\text { protection }\end{array}$ & $\begin{array}{l}\text { protection } \\
\text { of biodiversity }\end{array}$ & $\begin{array}{l}\text { development of the } \\
\text { tourist industry, tour- } \\
\text { ist complexes vs sus- } \\
\text { tainable tourism }\end{array}$ & $\begin{array}{l}\text { sustainable agricul- } \\
\text { ture vs Growth of in- } \\
\text { tensive agricultural } \\
\text { production }\end{array}$ & $\begin{array}{l}\text { participation } \\
\text { of local actors }\end{array}$ & $\begin{array}{c}\text { nature } \\
\text { protection issue }\end{array}$ & $\begin{array}{c}\text { local } \\
\text { development }\end{array}$ \\
\hline \multicolumn{8}{|c|}{ Number (Tab. 2) } \\
\hline 1 & -0.75 & -0.75 & -0.75 & -0.75 & -0.75 & -0.750 & -0.75 \\
\hline 2 & -0.25 & -0.50 & -0.50 & -0.75 & -0.75 & -0.375 & -0.67 \\
\hline 3 & 0.75 & 0.75 & -0.75 & -0.75 & -1.00 & 0.750 & -0.83 \\
\hline 4 & -0.75 & -1.00 & -0.75 & -0.75 & -1.00 & -0.875 & -0.83 \\
\hline 5 & 0.75 & 0.50 & 0.75 & 0.75 & 0.75 & 0.625 & 0.75 \\
\hline 6 & 0.75 & 0.75 & 0.75 & 1.00 & 0.75 & 0.750 & 0.83 \\
\hline 7 & 0.75 & 0.75 & 0.75 & 0.75 & 0.75 & 0.750 & 0,75 \\
\hline
\end{tabular}


Table 4. Main Landsat image metadata used (all scenes are diurnal; map projection: UTM)

\begin{tabular}{|c|c|c|c|c|c|}
\hline Metadata & Date 1 & Date 2 & Date 3 & Date 4 & Date 5 \\
\hline $\begin{array}{l}\text { Landsat } \\
\text { chosen scene }\end{array}$ & $\begin{array}{l}\text { LT519203519951 } \\
\text { 98MPS00 }\end{array}$ & $\begin{array}{l}\text { LE71920352000 } \\
\text { 188FUI00 }\end{array}$ & $\begin{array}{l}\text { LE71920352005 } \\
\text { 185EDC00 }\end{array}$ & $\begin{array}{c}\text { LT51920352010 } \\
191 M P S 00\end{array}$ & $\begin{array}{c}\text { LC81920352015 } \\
\text { 189LGN00 }\end{array}$ \\
\hline Sensor & Landsat 4-5 TM & Landsat 4-5 TM & Landsat 4-5 TM & Landsat 4-5 TM & Landsat 8 OLI \\
\hline Acquisition date & 17 July 1995 & 6 July 2000 & 4 July 2005 & 10 July 2010 & 8 July 2015 \\
\hline $\begin{array}{l}\text { Quality } \\
\text { of acquisition }\end{array}$ & 7 & 9 & 9 & 9 & 9 \\
\hline Sun height & 55.1625227 & 65.05884552 & 64.8292847 & 64.53377498 & 66.38993346 \\
\hline Sun azimut & 105.135257 & 115.85044861 & 114.7677917 & 116.13576737 & 118.9491555 \\
\hline Datum & WGS84 & WGS84 & WGS84 & WGS84 & WGS84 \\
\hline
\end{tabular}

to atmospheric effects (clouds, dust and other meteors) which makes vision and image interpretation sometimes difficult. We selected images that were almost undisturbed by cloudiness. In addition, we chose to focus on images of identical months to make our comparison more robust. This is why we have chosen the month of July for the available years of our study period. The aim is to focus on the state of vegetation in the Mediterranean region just at the time of summer hydric stress. Our goal is to measure whether there has been a positive evolution of forest cover over the last decades. With the selected images, our study takes into account variations in inter-annual weather conditions. These conditions have an impact on the state of water availability in soils for plants. However, according to the scientific literature, forest cover, and the mosaics of natural landscapes that accompany it, in regions with a dry season climate are less affected by variations in inter-annual climatic conditions than by local soil conditions, especially soil water holding capacity (Gergel et al. 2007; Pueyo et al. 2012). In this study, images of the Moderate Resolution Imaging Spectroradiometer (MODIS) were also used on the NASA TERRA satellites designed for the study and monitoring of the broadscale environment (biosphere, hydrosphere, atmosphere) with a spatial resolution of $250 \mathrm{~m}$ (for red and infrared from 0.6 to $0.9 \mu \mathrm{m}$ ). MODIS has a very good radiometric resolution (12bits) and captures images of the surface of the globe in 36 spectral bands ranging from visible (405 $\mathrm{nm})$ to thermal infrared $(14.385 \mu \mathrm{m})$. Normalized Difference Vegetation Index (NDVI) data is usually used to track ecosystem states and changes, with an analysis of the relationship between precipitation and the temporal evolution of this indicator (Kozuchowski \& Zmudzka 2001; Vagen 2006; Williamson et al 2012).

To maximize the benefits of satellite imagery, it is necessary to reduce or eliminate errors embedded in sensor data, atmospheric and lighting effects, and improper image overlay. For the present study, the radiometric and geometric corrections were applied to the LANDSAT TM and OLI images used, for useful predictive parameters.

Defined by Tucker (1979), NDVI is a vegetation index commonly used in vegetation monitoring studies. There are many applications of NDVI, Normalized Difference Vegetation Index (Pettorelli et al., 2005): deforestation assessments, forest fire monitoring, desertification monitoring, and even insect damage (Jepsen et al 2009). The NDVI is used to detect vegetation cover. It is calculated from spectral reflectance measurements in the red band in combination with near-infrared regions and is derivable with the equation: 
$N D V I=((I R-R) /(I R+R))$

(Tucker 1979; Myneni et al. 1995)

Where $I R$ is the pixel values of the infrared channel, between 0.55 and $068 \mu \mathrm{m}$, and $R$ is the pixel values of the red channel, between 0.73 and $1.1 \mu \mathrm{m}$. The theoretical values of NDVI are between -1 and 1 (between 0.1 and 0.9 for vegetation) (Doll 2010). Huete et al. (2002) consider that this index is sufficiently stable enough to allow comparisons of plant activity at seasonal or inter-annual time steps.

Change detection is the process of identifying the variation of an object or phenomenon over time, observing it at different times. It involves the ability to quantify temporal effects using multi-temporal datasets (Kożuchowski \& Żmudzka 2001). The 'change detection' operation consists of subtracting the NDVI values from a first image (or anterior image) to the next (or posterior image), pixel by pixel, then determining the comparison classes according to the degree of change between the two (Mariotto 2010).

$\operatorname{NDVI}\left(X_{i}\right)-\operatorname{NDVI}\left(X_{j}\right)=$ = Change detection (Xij) (Mariotto 2010)

Where $X i$ are the pixels of the previous date; $X_{j}$ are the pixels of the following date; $X_{i j}$ is the difference in pixels between dates $i$ and $j$.

There are generally three classes:

- Pixels with a value greater than 0 reflect areas that have experienced vegetation enrichment from date l;

- Pixels whose value is 0 are the areas that have not changed during the period $i-j$;

- Pixels with a negative value correspond to places where the vegetation cover has regressed.

\section{Results and discussion Analysis of socio-economic statistics}

The study focuses on the socio-economic evolution of the EKNP. According to the statistical data, the EKNP experienced a population growth from 126,781 inhabitants in 2008 to 141,920 inhabitants in 2015 . This growth $(12 \%)$ is part of a general growth for decades in Algeria. This protected area is not an empty rural area. The human density is high with a rate of 128 inhabitants $/ \mathrm{km}^{2}$ in 2015. However, population growth is concentrated in the areas of the coastal plain. Agricultural activity has grown strongly for several decades. Algeria entered the agricultural revolution early, with widespread modernization of crops and some forms of livestock farming, including cattle breeding for milk and meat production. The EKNP is characterized by a development of a productivist agriculture essentially in the north, in the coastal plain. There is, however, extensive livestock rearing of sheep grazing pastures in the mountains. Yet, there is no agriculture oriented toward organic or rational production.

However, the EKNP is a heavily forested area for Algeria with $69 \%$ of its area. The cork oak forest with $36 \%$ of this area and the eucalyptus forest with $37 \%$ dominate in the mountainous regions, to the south. The forest is old but it does not give rise to any productive management. On the other hand, forest fires represent a destruction that affects on average $10 \%$ of the forest area of EKNP per year (Bouazouni 2004).

Tourism activities are mainly concentrated on the coast. All of the current accommodation structures are located in the north. Statistics are failing on this sector. Yet a mass of tourists come in summer on the beaches of the coast. They are essentially nationals. Algeria has developed tourism but major development plans concern an industrial tourism activity (SDAT - see Tab. 2). This is reflected in the projects of seaside resorts. The goal is to enable the employment in tourist economy and development of the construction industries. However, since the SDAT (2008), the projects of creation of tourist resorts on the coast of the EKNP did not succeed. This reflects the important contradiction between tourism potential and investment capacity. Public policies aim at the creation of large seaside resorts. On the other 
hand, no strategy is developed towards sustainable tourism in relation to the potential of the protected area.

\section{Analysis of conservation and local development strategy documents}

Strategic documents concerning nature protection and local development have been studied and a representation of the data in Table 3 is given in Figure 3.

According to Table 3 and Figure 3 , the four documents corresponding to the public policies of Algeria and EKNP do not integrate the sustainable development approach. In circle A, 3 documents corresponding to the three protected areas are represented: the Kruger Park in South Africa, the Montsant Park in Spain and the Camargue Regional Nature Park in France. Circle B is the document describing the nature conservation strategy of the EKNP. It aims at the protection of biodiversity but it incorporates few concerns about economic development and not at all the local consultation of the populations concerned. Circle $\mathrm{C}$ brings together the EKNP documents and the SDAT that specify public policies in development. The solutions are exclusively unsustainable, neither for agriculture nor for tourism. In addition, no policy of consultation of the local populations is envisaged.

\section{Satellite data analysis}

The analysis that has been conducted on annual average rainfall for each year of satellite image observations demonstrates a good linear relationship between the variability of rainfall and that of the area of vegetation. In addition, a monthly treatment of these rainfall values demonstrates that soil moisture conditions follow the same variability of rainfall and that they are the ones that also determine changes in vegetation cover. However, if the precipitation curve shows significant variations (Fig. 4), the vegetation cover follows a more stable progression between 1995-2015.

This was not without positive consequences for the hydrology of the lakes, the dynamics of aquatic vegetation, agriculture and rangeland management in recent years (Boumaraf 2010). It should be noted that this change in vegetation area is not solely due to climatic conditions and that there are other factors that have contributed to the increase in vegetation cover, in particular the effects of conservation policies.

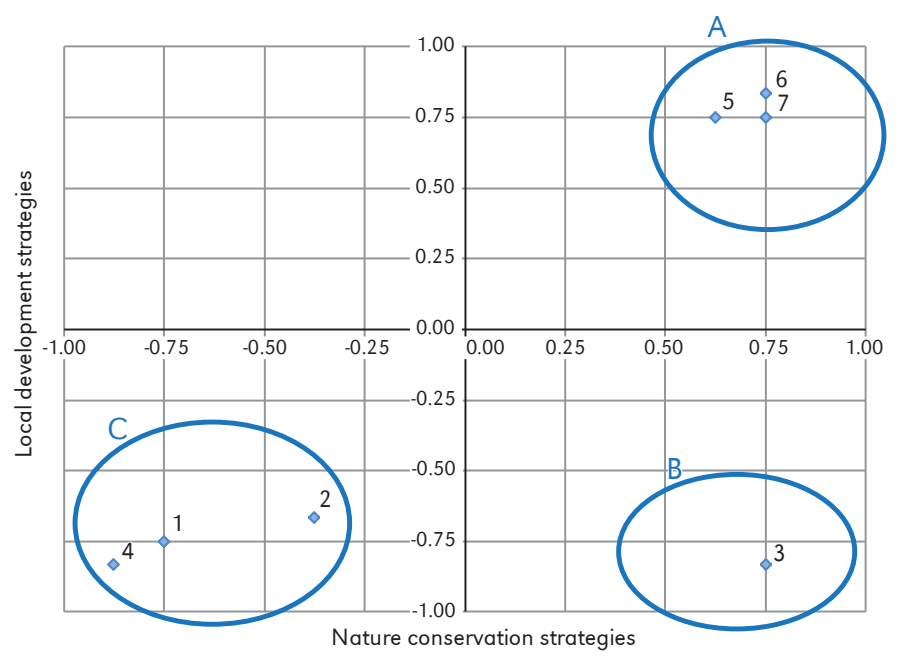

Figure 3. Representation of data corresponding to nature conservation and local development strategies (see Tab. 3) 


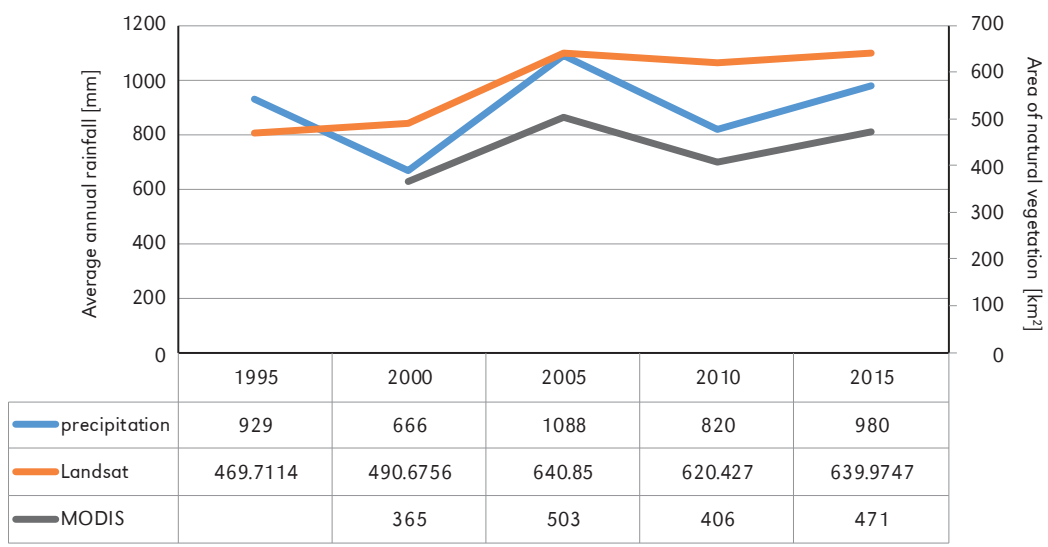

Figure 4. Average annual precipitation and vegetation cover curves calculated from Landsat and MODIS imagery in El Kala National Park between 1995-2015

The calculation of the NDVI index allowed us to observe and quantify the state of the vegetation in the EKNP over a period of 25 years. This analysis was applied to LANDSAT 4-5 TM and 8OLI LANDSAT images with $30 \mathrm{~m}$ resolution. In addition, we used $250 \mathrm{~m}$ resolution MODIS images, taken during the same periods as LANDSAT, to help us confirm the evolution of the vegetation. The results obtained by calculating the NDVI index on the LANDSAT images allowed us to observe a significant increase in the plant cover of the EKNP between 1995-2005, whereas the period 2005-2010 appears quite stable. A majority of the positive changes were located around the EKNP lakes (Lake Oubeira, Lake El Mellah and Lake Tonga). The study area is a rural area and agriculture is the dominant sector of activity, so the presence of a large number of lakes allows for a paradoxical evolution. Indeed, the lakes, and more particularly that of Oubeira, is the source of irrigation for the main crops in the region. The development of agriculture in the vicinity of Lake Oubeira has the effect of reducing lawn and forest areas (Hamouda \& Tahar 2012). Vegetation outside wetlands is essentially xerophile. Rainfall variations, especially during the most abundant years, have little impact on overall vegetation. The lake area increases during the wetter period, but paradoxically this leads to a decrease in the natural vegetation due to the increase in pastoral routes increase.

The period between 1995 and 2005 was marked by an increase in the total area of vegetation from $469 \mathrm{~km}^{2}$ to $640 \mathrm{~km}^{2}$, an evolution of $36.46 \%$. It is noted that shrub vegetation is the most advanced class compared to dense vegetation; this is explained by the highly developed agricultural activity in this period as a dominant sector for the local population. In addition, the regression of the class of bare ground of $280 \mathrm{~km}^{2}$ to $101 \mathrm{~km}^{2}$ (or $-63 \%$ ) confirms the progression of the natural and agricultural vegetation cover.

The last 10 years have been marked by a stable vegetation cover that has not undergone any major changes, apart from a significant increase in dense forest vegetation from 185.771 to $267.435 \mathrm{~km}^{2}$. On the other hand, a small regression between 2005 and 2010 affected the shrub vegetation from $455.079 \mathrm{~km}^{2}$ to $352.9918 \mathrm{~km}^{2}$. This is due to various factors such as fires, and overgrazing, which affect the landscape and biodiversity of the EKNP. These facts can lead to significant degradation of some ecosystems (Bougherara 2011). Contraction of forests and extension of agricultural land are the main changes that mark the evolution of the park's landscapes or wetlands in recent decades. 
The use of MODIS images was incorporated into this study to help us confirm the EKNP vegetation cover for the selected period. According to our results from the MODIS image study, there are significant positive changes between 2000 and 2005, particularly in the northern part, around the lakes where the vegetation area has increased by more than $37 \%$, from $365 \mathrm{~km}^{2}$ to $503 \mathrm{~km}^{2}$ between 2000-2005.

Table 5 shows the area variations for both types of images. Since 2005, the rate of evolution of vegetation varies between regression and progression, from $503 \mathrm{~km}^{2}$

Table 5. Area of vegetation during the period selected for LANDSAT images

\begin{tabular}{|l|c|c|c|c|c|}
\hline & \multicolumn{5}{|c|}{ Area in $\mathrm{km}^{2}$ (Landsat images) } \\
\cline { 2 - 6 } & NDVI 1995 & NDVI 2000 & NDVI 2005 & NDVI 2010 & NDVI 2015 \\
\hline $\begin{array}{l}\text { Dense vegetation, } \\
\text { forest }\end{array}$ & 170.6462 & 180.4621 & 185.771 & 267.435 & 171.9631 \\
Shrub vegetation & 298.7483 & 310.2135 & 455.079 & 352.9918 & 468.0116 \\
Bare ground & 280.467 & 253.137 & 101.481 & 121.819 & 105.1043 \\
Wet area & 21.24 & 27.76 & 29.19 & 29.46 & 26.63 \\
\hline Total & 771.42 & 771.57 & 771.51 & 771.70 & 771.70 \\
\hline
\end{tabular}

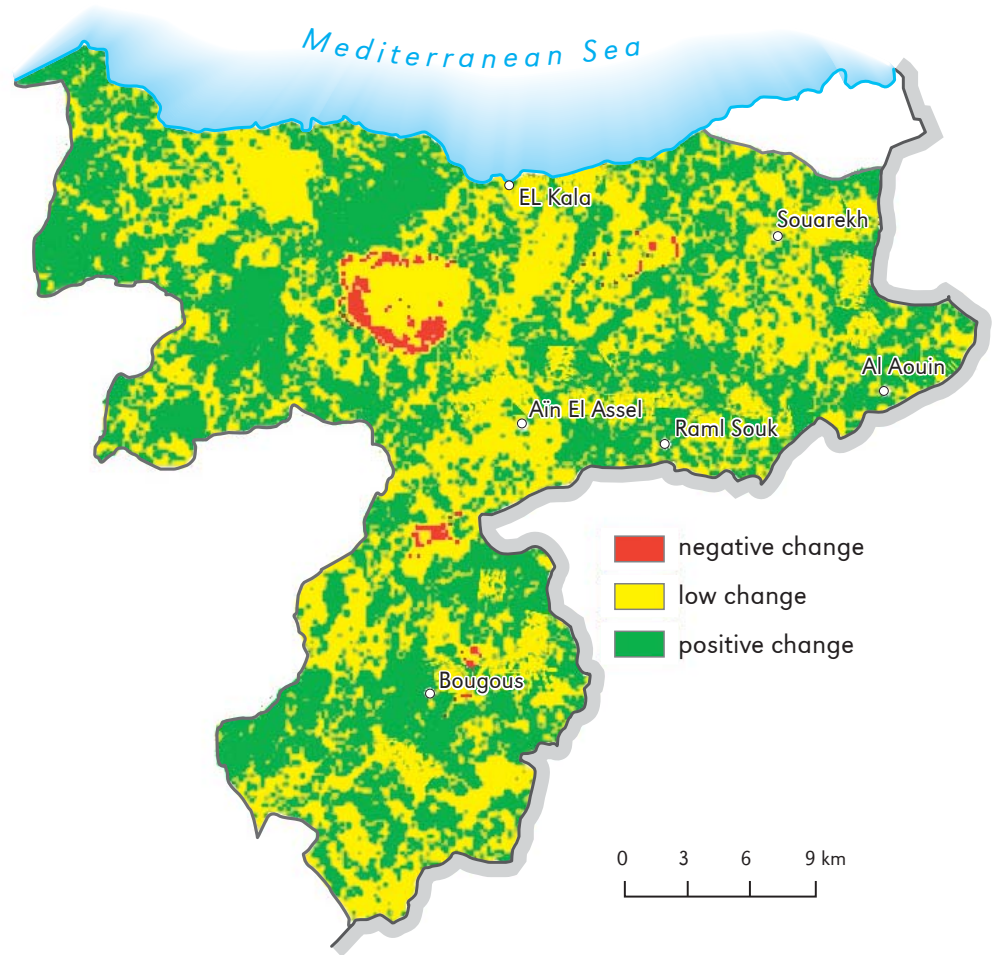

Figure 5. Vegetation changes based on Landsaet images between 1995 and 2015 from the processing of data taken from LANDSAT images 
to $406 \mathrm{~km}^{2}$, a regression of $-23 \%$, and then a slight increase until 2015 of 16\%. Despite the spatial resolution of MODIS $250 \mathrm{~m}$ images, the same vegetation evolution results were observed between 2000-2015. This period was marked by an increase in vegetation area from $469 \mathrm{~km}^{2}$ to $640 \mathrm{~km}^{2}$, an evolution of $36.46 \%$. On the other hand, over the last 10 years, this was a period of stability for vegetation. It has not undergone any major changes, apart from a small regression of about $2 \mathrm{~km}^{2}$ between 2005 and 2010, due to the same factors as in the previous analysis. The reduction of forests and the extension of agricultural land are the main changes that mark the evolution of the landscape or wetlands of the park in recent decades. Map obtained after NDVI treatment (Fig. 5) shows changes within EKNP from 1995 to 2015. Limited negative changes have occurred in the hygrophilous vegetation cover of Tonga Lake (northeast of the park). In the same Figure, we notice that the region of Lake Oubeira (located north of the park) has experienced major negative changes. This sector has been exploited since the end of the 1970s, because of its attractiveness for agricultural activities. This increased exploitation in wetlands has led to significant degradation of its ecosystem.

In contrast, the El Mellah Lake area (northwest of the park) has had much more positive changes. These results are due to the fact that it has been spared from human activity. This evolution can be explained on the one hand by the nature of the soils, which include marine sands. On the other hand, the proximity of Lake El Mellah to the coastline, which increases the salinity of its water (Hamouda \& Tahar 2012).

\section{Conclusion}

In our study, it is shown that there are two contradictory public policies concerning the case of the El Kala National Park. However, public policies of nature conservation are effective. Indeed, our study, resulting from the processing of LANDSAT images, shows an increase in the area of EKNP vegetation between 1995 and 2005 by more than 36\%, or an area of $171 \mathrm{~km}^{2}$. On the other hand, the observations from 2005 of the variations up to 2015 show that the vegetation did not have any significant positive changes. Indeed, an increase in the rural population has generated a radical transformation of the use of the environment: deforestation, overgrazing, urbanization and fires. Locally, the extension of irrigated crops takes place at the expense of wetlands. These phenomena profoundly disturb natural ecosystems. Safeguarding them requires the development of policies that conserve biodiversity and endangered habitats.

An important part of the EKNP has had a significant increase in its vegetation and this testifies to the effectiveness of the Algerian State's policies for the conservation of nature. Nature conservation issues concern the contribution to the preservation of the fauna and flora richness of the Mediterranean region. As has been demonstrated by Rykowski (1999), forests play an important role in reducing climate change, particularly through their carbon sequestration activity (Rykowski 1999). They also make it possible to fight against soil erosion and floods (Lefevre et al. 2013). As more and more scientists point out, the management of protected areas now involves a desire to reconcile multiple and varied issues by integrating the concerns of sustainable development, for example by promoting controlled and accepted agricultural and tourism activities by local populations (Balmford et al. 2002; Kalamandeen \& Gillson 2007; Rudel 2011; Pfueller et al. 2011; Tomicevic et al. 2011). All this implies the cohabitation of areas, natural environments, wild fauna and flora, with a certain presence and attendance of temporary populations, guided or demarcated visits, or even for permanent populations occupying the area protected to practice agricultural activities in harmony with the conservation of nature (Mathevet \& Mauchamp 2005; Pfueller et al. 2011; Mathevet et al. 2016).

Created in the 1970s, the global network of Man and Biosphere (MAB) reserves, led 
by the United Nations, is a witness to this evolution and even the International Union for the Conservation of Nature (IUCN), International Union for the Conservation of Nature, agrees favorably, within the protected areas, for the association of nature conservation and development objectives, especially since the current approaches include the protection of the natural and cultural heritage, with the aim of safeguarding rural traditions and activities (Tomicevic et al. 2011; Mathevet et al. 2016). Particularly in Africa, such as in South African Kruger Park (Venter et al. 2008), development efforts are integrated with sustainability goals. Agricultural activities rely on traditional or non-intensive practices. Tourism practices are activities of nature tourism, such as hiking that may include insertion into the landscape, accommodation built using local materials. In some

\section{References}

ABMAN R., 2018. Rule of law and avoided deforestation from protected area. Ecological Economics, vol. 146, pp. 282-289.

AsHBINDU S., 1989. Review article digital change detection techniques using remotely-sensed data. International Journal of Remote Sensing, vol. 10, no. 6, pp. 989-1003.

Balmford A., Bruner A., Cooper P., Costanza R., Farber S., Green R.E., Jenkins M., Jefferiss P., Jessamy V., Madden J., Munro K., Myers S., Nacem S., Paavola J., Rayment M., Rosendo S., ROUghgarden J., Trumper K., TUneR R.K., 2002. Economic reasons for conserving wild nature. Science, vol. 297, no. 5583, pp. 950-953.

Benyacoub S., Chabi Y., 2000. Diagnose Ecologique de l'Avifaune du Parc National d'El-Kala. Synthèse, vol. 7, no. 6, Revue des Sciences et Technologie, Université Annaba, pp. 3-98.

Bouazouni O., 2004. Projet régional pour le développement d'aires marines et côtières protégées dans la région de la Méditerranée, Parc National d'El Kala, étude socio-économique du PNEK. United Nations Environment Programme, Mediterranean Action Plan, Regio- cases, as shown for Sahara by Santarem et al. (2019), innovative tools are developed to integrate biodiversity conservation dynamics with collaborative practices involving a plurality of actors (Weiss et al. 2007; Pfueller et al. 2011; Tomicevic et al. 2011; Rykowski 2012; Muhumuza et al. 2013): what Weber et al. (2012) expresses in the form of cumulative effects. Many examples exist and Algeria can follow suit according to an integrated approach of its socio-ecological systems (Balmford et al. 2002; Ostrom 2009; Tomicevic et al. 2011).

Editors' note:

Unless otherwise stated, the sources of tables and figures are the authors', on the basis of their own research.

nal Activity Centre for Specially Protected Areas.

Bougherara A., 2011. Identification et suivi des paysages et de leur biodiversité dans la Wilaya d'el Tarf (Algérie) à partir des images Landsat, Spot et Aster. Télédétection, Contemporary Publishing International, Editions Scientifiques Gb, vol. 9, no. 3-4, pp. 225-243.

Boumaraf W., 2010. Cartographie et impact de la qualité des eaux du lac Oubeira sur la relation sol-végétation (Parc National d'El Kala). Université Annaba [PhD Thesis].

BRANDT J., THORNES J. (eds.), 1996. Mediterranean desertification and land use. Chichester: Wiley.

De Belair G., 1990. Structure, fonctionnement et perspectives de gestion de quatre éco-complexes lacustres et marécageux (El - Kala, est algérien). Université Montpellier 2, [PhD Thesis].

Doll D., 2010. Apport et analyse des images satellites MODIS pour le suivi des douglassaies en bourgogne. Université de Bourgogne, Centre Régional de la Propriété Forestière.

Facuccl A., MaIORano L., Boltani L., 2007. Changes in land-use/land-cover patterns in Italy and their implications for biodiversity 
conservation, Landscape Ecology, vol. 22, no. 4, pp. 617-631.

Generalitat de Catalunya, 2009. Agenda 21, Parc Natural de la Serra de Montsant.

Geosystem consulting, 2013. Etude pour l'élaboration du plan d'aménagement cotier (Wilaya $d^{\prime} E$ I Tark). Ministère de l'Aménagement du Territoire et de l'Environnement, Alger.

Gergel S.E., Stange Y., Coops N.C., Johansen K., KIRBY K.R., 2007. What is the value of a good map? An example using high spatial resolution imagery to aid riparian restoration, Ecosystems, vol. 10, no. 5, pp. 688-702.

Hamouda S., Tahar A., 2012. Apport de l'analyse spatiale dans le suivi du couvert végétal du parc national d'El Kala, (Algérie). Synthèse: Revue des Sciences et de la Technologie, vol. 25, no. 1, pp. 59-70.

Held T., Montero Küpper K., 2001. Unsustainable forestry causes forest fires. A case study from Galicia (North-West Spain). Geographia Polonica, vol. 74, pp. 65-76.

Huete A., Didan K., Miura T., Rodriguez E.P., Gao X., Ferreira L.G., 2002. Overview of the radiometric and biophysical performance of the MODIS vegetation indices, Remote Sensing of Environment, vol. 83, no. 1-2, pp. 195-213.

Jepsen J.U., Hagen S.B., Hogda K.A., Ims R.A., Karisen S.R., TOMmerVIK H., Yoccoz N.G., 2009. Monitoring the spatio-temporal dynamics of geometrid moth outbreaks in birch forest using MODIS-NDVI data. Remote Sensing of Environment, vol. 113, no. 9, pp. 1939-1947.

Joppa L.N., Pfaff A., 2010. Global protected area impacts. Proceedings of the Royal Society B, vol. 278, no. 1712, pp. 1633-1638.

Kalamandeen M., Gillson L., 2007. Demything "wilderness": Implications for protected area designation and management. Biodiversity Conservation, vol. 16, no. 1, pp. 165-182.

Kefi S., Rietkerk M., Alados C.L., Pueyo Y., PapaNASTASIS V.P., De RuIter P.C., 2007. Spatial vegetation patterns and imminent desertification in Mediterranean arid ecosystems. Nature, vol. 449, no. 7159, pp. 213-217.

Klausmeyer K.R., Shaw M.R., 2009. Climate change, habitat loss, protected areas and climate adaptation potential of species in Mediterranean ecosystems worldwide. PLoS one, vol. 4, no. 7: e6392.
KoŻUCHOWsKI K., ŻMUDZKA E., 2001. Assessment of relations between the normalized difference vegetation index (NDVI), frequency of forest fires, air temperature, sunshine, precipitation in Poland. Geographica Polonica, vol. 74, no. 2, pp. 29-40.

Lefevre F., Palahi M., Dupuy J-L., Fady B., Gonzalez Martinez S., Huc R., Muys B., Rigolot E., 2013. Adaptive management and restoration practices in Mediterranean forests [in:] State of Mediterranean Forests, FAO - Food and Agriculture Organisation, https://hal.archivesouvertes.fr/hal-01594318/document [19 April 2019].

Malek Z., Verburg P.H., Geijzendorffer I.R., Blondeau A., Cramer W., 2018. Global change effects on land management in the Mediterranean region. Global Environmental Change, vol. 50, pp. 238-254.

Mare Nostrum \& Agro-3, 2009. Agenda 21 de Montsant, Diputacio de Tarragona, http://parcsnaturals.gencat.cat/web/.content/ home/serra_de_montsant/coneix-nos/instruments_de_planificacio_i_gestio/plans_i_programes_especifics/43_148704.pdf [19 April 2019].

Mariotto I., Gutschick V.P., 2010. Non-lambertian corrected albedo and vegetation index for estimating land evapotranspiration in a heterogeneous semi-arid landscape. Remote Sensing of Environment, vol. 2, no. 4, pp. 926-938.

Mathevet R., Mauchamp A., 2005. Evidencebased conservation: Dealing with social issues. Trends in Ecology and Evolution, vol. 20, no. 8, pp. 422-423.

Mathevet R., Thompson J.D., Folke C., ChapIN F.S., 2016. Protected areas and their surrounding territory: socioecological systems in the context of ecological solidarity. Ecological Applications, vol. 26, no. 1, pp. 5-16.

Matuszkiewicz J.M., Wolski J., Kowalska A., 2013. A map of sequences of "forest/non-forest" states over the last 200 years in the borderland between Poland's Masuria and Kurpie regions, Geographia Polonica, vol. 86, no. 4, pp. 393-402.

Medall F., 2017. The specific vulnerability of plant biodiversity and vegetation on Mediterranean islands in the face of global change. Regional Environmental Change, vol. 17, no. 6, pp. 1775-1790. 
Medail F., Quezel P., 1997. Hot-spots analysis conservation of plant biodiversity in the Mediterranean Basin. Annals of the Missouri Botanical Garden, vol. 84, no. 1, pp. 112-127.

Ministère de l'Aménagement du Territoire, de l'EnVIRONNEMENT ET DU TOURISME, 2008. Schéma directeur d'aménagement touristique, SDAT 2025. Alger, 5 volumes.

Muhumuza M., Sanders M., Balkwill K., 2013. A theoretical framework for investigating ecological problems associated with biodiversity conservation in national parks: A case of the Rwenzori mountains national park, Uganda. Open Journal of Ecology, vol. 3, no. 2, pp. 196-204.

Myneni R.B., Hall F.G., Sellers P.J., Mashak A.L., 1995. The interpretation of spectral vegetation indexes. IEEE Transactions on Geoscience and Remote Sensing, vol 33, no. 2, pp. 481-486.

Ostrom E., 2009. A general framework for analysing sustainability of social-ecological systems. Science, vol. 325, no. 5939, pp. 419-422.

Ouelmounoub S., 2005. Gestion multi-usage et conservation du patrimoine forestier: cas des subéraies du parc national d'El Kala (Algérie). Series Master of Science, Montpellier: Centre international de hautes études agronomiques méditerranéennes, Institut Agronomique Méditerranéen de Montpellier.

Parc Naturel Régional de Camargue, 2010. Charte. Objectif 2022. Rapport Vol. 1. http:// www.provence-plaisirs.com/pdf/charte_parc_ naturel_camargue.pdf [28 Feb. 2019].

Pech P., Arques S., Jomelli $\vee$., Malllet I., Melois N., Moreau M., 2007. Spatial and temporal biodiversity variations in a high mountain environment: The case of proglacial margin of the Evettes, Natura 2000 area (Savoie, French Alps). Cybergeo: European Journal of Geography, vol. 374.

Pettorelli N., Vik J.O., Mysterud A., GallLard J-M., Tucker C.J., Stenseth N.C., 2005. Using the satellite-derived NDVI to assess ecological responses to environmental change. Trends in Ecology \& Evolution, vol. 20, no. 9, pp. 503-510

Pfueller S.L., Lee D., Laing J., 2011. Tourism partnerships in protected areas: Exploring contributions to sustainability. Environmental Management, vol. 48, no. 4, pp. 734-749.
Pueyo Y., Moret-Fernandez D., Saiz H., Bueno C.G., Alados C.L., 2013. Relationships between plant spatial patterns, water infiltration capacity, and plant community composition in semi-arid Mediterranean ecosystems along stress gradient. Ecosystems, vol. 16, no. 3, pp. 452-466.

PYKE C.R., 2007. The implications of global priorities for biodiversity and ecosystem services associated with protected areas. Ecology and Society, vol. 12, no. 4, http://www.ecologyandsociety.org/vol12/iss1/art4/ [28 Feb. 2019].

Quézel P., MédAil F., 2003. Écologie et biogéographie des forêts du bassin méditerranéen. Paris: Elsevier.

RibeiRo R.P., Borges J.G., Oliveira V., 2004. A framework for data quality for Mediterranean sustainable ecosystem management. Annals of Forest Science, vol. 61, no. 6, pp. 557-568.

RINAUDO Y., 1988. La forêt méditerranéenne d'hier à aujourd'hui, le cas de la Provence. Forêt Méditerranéenne, vol. 10, no. 1, pp. 20-25.

RUDEL T.K., 2011. Local actions, global effects? Understanding the circumstances in which locally beneficial environmental actions cumulate to have global effects, Ecology and Society, vol. 16, no. 2, art. 19, http://www.ecologyandsociety.org/vol16/iss2/art19/ [28 Feb. 2019].

RYKOWSKI K., 1999. Assessment of the importance of forests in reducing global climatic change (counteracting and mitigating the impacts of greenhouse gases). Geographia Polonica, vol. 72, no. 2, pp. 27-43.

RYKOWSKI K., 2012. The basics of sustainable forest management in forest promotional complexes. Geographia Polonica, vol. 85, no. 2, pp. 47-55.

Santarem F., Pereira P., Saarinen J., Brito J.C., 2019. New method to identify and map flagship fleets for promoting conservation and ecotourism. Biological Conservation, vol. 229, pp. 113-124.

Thompson R.S., Anderson K.H., Bartlein P.J., 1999. Atlas of relations between climatic parameters and distributions of important trees and shrubs in North America. U.S. Geological Survey Professional Paper, 1650, Denver, CO: U.S. Department of the Interior, U.S. Geological Survey.

Tomicevic J., Bjedov I., Obratov-Petkovic D., MiLOVANOVIC M., 2011. Exploring the park-people relation: Collection of Vaccinium myrtillus $L$. 
by local people from Kopaonik National Park in Serbia. Environmental Management, vol. 48, no. 4, pp. 835-846.

TuCKER C.J., 1979. Red and photographic infrared linear combinations for monitoring vegetation. Remote Sensing of Environment, vol. 8, no. 2, pp. 127-150.

VAGEN T.G., 2006. Remote sensing of complex land use change trajectories - a case study from the highlands of Madagascar. Agriculture, Ecosystems \& Environment, vol. 115, no. 1-4, pp. 219-228.

Venter F.J., Naiman R.J., Biggs H.C., Et Al PienAAR D.J, 2008. The evolution of conservation management philosphy: Science, environnemental change and social adjustements in Kruger National Park. Ecosystems, vol. 11, no. 2, pp. 173-192.
Weber M., Krogman N., Antoniuk T., 2012. Cumulative effects assessment: Linking social, ecological and governance dimensions. Ecology and Society, vol. 17, no. 2, https://www.jstor. org/stable/26269026 [28 Feb. 2019].

Weiss G., Martin S., Matilainen A., Vennesland B., Nastase C., Nybakk E., Bouriaud L., 2007. Innovation processes in forest-related recreation services: The role of public and private resources in different institutional backgrounds. Small-scale Forestry, vol. 6, no. 4, pp. 423-442.

Williamson J.C., Bestelmeyer B.T., Peters D.P.C., 2012. Spatiotemporal patterns of production can be used to detect state change across an arid landscape. Ecosystems, vol. 15, no. 1, pp. 34-47. 